\title{
KONSTRUKSI PENDIDIKAN MULTIKULTURAL DALAM PEMBELAJARAN PENDIDIKAN AGAMA ISLAM BERBASIS MULTI AGAMA
}

\author{
Suharnianto \\ Sekolah SMKN 1 Pamekasan \\ Email : yantosuharni69@gmail.com
}

\begin{abstract}
Abstrak
Penelitian ini bertujuan untuk mendeskripsikan dan menganalisis; eksternalisasi, objektivasi, dan internalisasi nilai-nilai pendidikan multikultural dalam pembelajaran pendidikan agama Islam berbasis multiagama di SMKN 3 Kabupaten Pamekasan. Metode penelitiannya menggunakan pendekatan kualitatif berjenis fenomenologi. Hasil penelitian menunjukkan: pertama eksternalisasi, yaitu penyesuaian diri dengan budaya dan pendidikan yang ada di lembaga. Kedua objektivasi, yaitu sebuah interaksi antara guru dan murid saat menjalankan proses pendidikan, dan guru memberikan contoh hal yang baik kepada peserta didik dengan berperilaku sopan santun dan saling menghormati. Ketiga internalisasi, yaitu individu mengidentifikasikan diri dengan lembaga, peserta didik merasa pendidikan sekolah multikultural menjadi bagian dari dirinya sehingga menjalankan tanpa ada paksaan dengan peserta didik menirukan hal yang diberikan guru pada peserta didik.
\end{abstract}

Kata kunci: konstruksi, nilai multikulturalisme, agama, peserta didik

\section{Abstract}

This study aims to describe and analyze; externalization, objectivity, and internalization of multicultural education values in the multi-religious based Islamic education learning at SMKN 3 Pamekasan. The research method uses a qualitative approach of phenomenological type. The results showed: first, externalization, namely self-adjustment to the culture and education in the institution. The second objectivity, which is an interaction between teacher and student during the education process, and the teacher provides examples of good things to students by behaving courtesy and mutual respect. The third is internalization, namely individuals identifying themselves with institutions, students feel multicultural school education becomes a part of themselves so that running without any compulsion with students imitate what teacher is given to students.

Keywords: construction, multiculturalism values, religion, students 


\section{PENDAHULUAN}

Pendidikan Agama Islam sedang mendapat tantangan karena ketidakmampuannya menciptakan kesadaran masyarakat akan pendidikan multikultural yang meniscayakan multi etnik, dan agama. Oleh karena itu tugas menyiapkan generasi umat yang bebas konflik dan kekerasan, maka kita berkewajiban menciptakan kader yang santun dan toleran. Di dalam sekolah tentu adanya norma prosedural, kode perilaku susunan struktural, distribusi kekuasaan, keistimewaan dan tanggung jawab, sekolah mencerminkan nilai-nilai kurtural masyarakatnya. Guru, administrator dan para pembuat kebijakan membawa pengalaman dan perspektif kultural sendiri dan memberikan pengaruh terhadap setiap keputusan dan tindakan pendidikan.

Agama seringkali menjadi pemicu timbulnya percikan-percikan api yang dapat menyebabkan konflik horizontal diantara pemeluk agama. Perbedaan agama yang dianut oleh masyarakat akan membawa perbedaan dalam kehidupan sehari-hari, misalnya cara berpakaian, cara bergaul, tata cara perkawinan, tata cara peribadatan, penerapan hukum warisan, dan corak kesenian. Perbedaan tersebut jika dijadikan masalah akan menimbulkan konflik antar pemeluk agama yang satu dengan pemeluk agama lainnya.

Konflik ini dapat menjadi besar dan lama tergantung dari pihakpihak yang bertikai. Aspek keberagamaan diakui atau tidak banyak menimbulkan berbagai persoalan sebagaimana yang kita lihat saat ini. Kurang mampunya individu-individu di Indonesia untuk menerima perbedaan itu. Sehingga mengakibatkan hal yang negatif. Banyak sekali kasus-kasus kekerasan yang terjadi di Indonesia yang berakar dari perbedaan.

Demikian pula dengan siswa yang berasal dari berbagai latar belakang etnik dan budaya di dalam suatu sekolah. Budaya yang berbeda inilah dapat menimbulkan konflik budaya, yang hanya dapat dimediasi dan direkonsiliasi melalui efektifitas proses intruksional yang mencerahkan dan membuka batasan-batasan kultural yang kaku.

SMKN 3 Pamekasan yang berlokasi di jalan Kabupaten No.103, Kecamatan Pamekasan, Kabupaten Pamekasan ini merupakan sekolah dengan siswa yang beranekaragam agama maupun suku menjadikan SMKN 3 Pamekasan menjadi unik dan kompleks. Terdapat kelas-kelas yang cukup besar, didalamnya terdapat berbagai macam bentuk siswa dari beberapa suku. Suasana di sekolah ini juga sangat asri dan sejuk, sehingga mendukung untuk digunakan sebagai tempat belajar.

Keberhasilan pendidikan multikultural di SMKN 3 Pamekasan sangat tergantung dari pengelolaan, atau perlu adanya manajemen yang 


\section{PENDIDIKAN MULTIKULTURAL}

baik. Pada dasarnya pengelolaan pendidikan multikultural merupakan suatu proses yang melibatkan tahap perencanaan, pelaksanaan, dan evaluasi. Dalam pelaksanaannya guru dalam hal ini sangat berperan untuk mengembangkan pengetahuan, dan sikap siswa mengenai makna multikultural sebenarnya. Pengelolaan pendidikan multikultural yang dilaksanakan oleh sekolah bertujuan memberikan pemahaman yang benar kepada siswa mengenai keragaman budaya, menanamkan jiwa solidaritas, memotivasi belajar siswa, sehingga mereka dapat bersosialisasi dengan masyarakat dengan sebaik-baiknya. SMKN 3 Pamekasan, sebagai salah satu lembaga pendidikan formal mengajarkan berbagai macam materi pelajaran, khususnya materi Pendidikan Agama Islam, dalam pembelajarannya SMKN 3 Pamekasan mengadakan suatu pengajaran baru untuk mengembangkan pendidikan Islam sesuai dengan tujuannya, maka diterapkan pendidikan multikultural pada materi pendidikan agama Islam sebagai bentuk materi pelajaran yang dapat dijadikan pedoman bagi peserta didik dalam menghadapi kehidupan pada masyarakat multikultural untuk saling menghormati dan menyadari akan keterbedaan sesama.

Oleh karena itu dalam pembelajarannya tidak hanya memiliki kencenderungan untuk mengajarkan pendidikan agama secara parsial (luarnya saja), akan tetapi mengajarkan secara menyeluruh disertai dengan berbagai macam perbedaan pendapat dan bentuk, misalnya Materi pendidikan agama, tidak hanya terfokus pada upaya mengurusi masalah keyakinan seorang hamba dengan Tuhannya. Seakan-akan masalah surga atau kebahagian hanya dapat diperoleh dengan cara ibadah atau aqidah saja, melainkan adanya hubungan antar sesama manusia.

Materi pelajaran Pendidikan Agama Islam yang diajarkan di SMKN 3 terindikasi bermuatan multikulturalitas. Dan atas dasar itulah kemudian multikulturalisme menjadi urgen diajarkan dan dijalankan. Dengan demikian peserta didik diharapkan mampu memahami, menghayati dan memiliki sikap menghormati, serta menghargai akan perbedaan dalam masyarakat multikultur, hendaknya memberikan materi yang berbasis multikultur tersebut ke dalam bentuk mata pelajaran yang berdiri sendiri, sehingga lebih terfokus dan mengetahui secara kompleks bagaimana pendidikan multikultural dikuasai oleh peserta didik.

Pembelajaran pendidikan agama Islam di SMKN 3 Pamekasan yang memberikan nilai multikultural adalah salah satu model pembelajaran pendidikan agama Islam yang dikaitkan pada keragaman yang ada, entah itu keragaman agama, etnis, bahasa dan lain sebagainya. Hal ini dilakukan sebagai usaha agar peserta didik mampu bersikap saling menghormati antar sesamanya yang berlainan etnis, bahasa, suku, dan lain sebagainya. Bila demikian, pendidikan agama menjadi lebih bermakna baik pada tataran 
sosiologis dan psikologis peserta didik, dan diharapkan mampu memberikan konstribusi dalam mewujudkan entitas kemanusiaan yang berperadaban. Jadi bisa dikatakan bahwa pendidikan Agama Islam berbasis multikultural adalah pengembangan pembelajaran pendidikan agama Islam yang dilandasi dengan nilai-nilai multikultural sehingga mampu mengantarkan siswa kepada kesalehan individual maupun kesalehan sosial.

Fenomena pola pembelajaran pendidikan Agama Islam sebagaimana uraian di atas menjadi unik dan menarik untuk kemudian dikaji dalam rangka menungkap dan menganalisis proses eksternalisasi, objektivasi, dan internalisasi nilai-nilai pendidikan multikultural dalam pembelajaran pendidikan agama islam berbasis multiagama di SMKN 3 Pamekasan ini dengan maksud menambah khzanah keilmuan pendidikan Agama Islam.

\section{METODE PENELITIAN}

Metode penelitian menggunakan pendekatan kualitatif berjenis fenomenologi, artinya penelitian ini dilakukan dengan maksud untuk memahami fenomena tentang apa yang dialami oleh subjek penelitian. Alasan digunakannya pendekatan ini adalah karena penelitian ini ingin lebih memahami secara lebih mendalam mengenai implementasi kebijakan yang diimplementasikan di SMKN 3 Pamekasan. Lexy J. Moleong menyatakan bahwa penelitian kualitatif adalah penelitian yang bermaksud untuk memahami fenomena tentang apa yang dialami oleh subyek penelitian misalnya perilaku, persepsi, motivasi, tindakan, dll., secara holistik, dan dengan cara deskripsi dalam bentuk kata-kata dan bahasa, pada suatu konteks khusus yang alamiah dan dengan memanfaatkan berbagai metode alamiah. ${ }^{1}$ Teknik pengumpulan datanya menggunakan metode wawancara, observasi, dokumentasi serta pengumpulan data dari berbagai sumber yang berkaitan.

Agar hasil peneliti dapat tersusun sistematis, maka langkah peneliti dalam menganalisis data adalah dimulai dengan menelaah seluruh data yang tersedia dari berbagai sumber, yaitu data dari wawancara, observasi, maupun data dari dokumentasi. Data tersebut tentunya sangat banyak, setelah dibaca dan dipelajari, maka langkah berikutnya adalah melibatkan tiga komponen analisis, yaitu: (1) reduksi data (data reduction), (2) penyajian data (data display), dan (3) penarikan kesimpulan (verification). Ketiga komponen analisis berdasarkan model interaktif Mile and Hubermen.

1 Lexy Moleong J, Metodologi Penelitian Kualitatif, (Bandung: Remaja Rosdakarya, 2012), 6. 


\section{PEMBAHASAN}

\section{Konstruksi Sosial}

Teori konstruksi sosial sebagaimana yang digagas oleh Berger dan Luckman $^{2}$ menegaskan, bahwa agama sebagai bagian dari kebudayaan merupakan konstruksi manusia. Ini artinya, bahwa terdapat proses dialektika antara masyarakat dengan agama. Agama yang merupakan entitas objektif (karena berada di luar diri manusia) akan mengalami proses objektivasi sebagaimana juga ketika agama berada dalam teks dan norma. Teks atau norma tersebut kemudian mengalami proses internalisasi ke dalam diri individu karena telah diinterpretasi oleh manusia untuk menjadi guidance atau way of life. Agama juga mengalami proses eksternalisasi karena agama menjadi sesuatu yang shared di masyarakat.

Teori konstruksi sosial ${ }^{3}$ dalam penelitian ini dijadikan sebagai guidance untuk melihat realitas sosial, karena menurut Berger dan Luckmann kontsruksi sosial dibangun melalui dua cara: Pertama, mendefinisikan tentang kenyataan atau "realitas" dan "pengetahuan". Realitas sosial adalah sesuatu yang tersirat di dalam pergaulan sosial yang diungkapkan secara sosial melalui komunikasi bahasa, kerjasama melalui bentuk-bentuk organisasi sosial dan seterusnya. Realitas sosial ditemukan dalam pengalaman intersubjektif, sedangkan pengetahuan mengenai realitas sosial adalah berkaitan dengan kehidupan bermasyarakat dengan segala aspeknya, meliputi ranah kognitif, psikomotorik, emosional dan intuitif.

Kedua, untuk meneliti sesuatu yang intersubjektif tersebut, Berger menggunakan paradigma berpikir Durkheim mengenai objektivitas, dan paradigma Weber mengenai subjektivitas. Jika Durkheim memposisikan objektivitas di atas subjektivitas (masyarakat di atas individu), sementara Weber menempatkan subjektivitas di atas objektivitas (individu di atas masyarakat), maka Berger melihat keduanya sebagai entitas yang tidak terpisahkan. Masyarakat menurut Berger merupakan realitas objektif sekaligus subjektif. Sebagai realitas objektif, masyarakat berada di luar diri manusia dan berhadapan dengannya. Sedangkan sebagai realitas subjektif, individu berada di dalam masyarakat sebagai bagian yang tak terpisahkan. Dengan kata lain, bahwa individu adalah pembentuk masyarakat dan masyarakat juga pembentuk individu. Realitas sosial bersifat ganda (plural) dan bukan tunggal, yaitu realitas objektif dan subjektif.

Realitas objektif adalah realitas yang berada di luar diri manusia, sedangkan realitas subjektif adalah realitas yang berada dalam diri manusia. Tahap eksternalisasi dan objektivasi merupakan pembentukan masyarakat

2 Peter L. Berger dan Thomas Lukhmann, Tafsir Sosial atas Kenyataan, (Jakarta: LP3ES, 1991). 1.

${ }^{3}$ Nur Syam, Islam Pesisir, (Yogyakarta: LKis Pelangi Aksara , 2005), 37. 
yang disebut sebagai sosialisasi primer, yaitu momen dimana seseorang berusaha mendapatkan dan membangun tempatnya dalam masyarakat. Dalam kedua tahap ini (eksternalisasi dan objektivasi) seseorang memandang masyarakat sebagai realitas objektif (man in society). Sedangkan dalam tahap internalisasi, seseorang membutuhkan pranata sosial (social order), dan agar pranata itu dapat dipertahankan dan dilanjutkan, maka haruslah ada pembenaran terhadap pranata tersebut, tetapi pembenaran itu dibuat juga oleh manusia sendiri melalui proses legitimasi yang disebut objektivasi sekunder. Pranata sosial merupakan hal yang objektif, independen dan tak tertolak yang dimiliki oleh individu secara subjektif. Ketiga momen dialektik itu mengandung fenomena-fenomena sosial yang saling bersintesa dan memunculkan suatu konstruksi sosial atau realitas sosial, yang dilihat dari asal mulanya merupakan hasil kreasi dan interaksi subjektif. Berger dan Luckmann mengatakan institusi masyarakat tercipta dan dipertahankan atau diubah melalui tindakan dan interaksi manusia. meskipun institusi sosial dan masyarakat terlihat nyata secara obyektif, namun pada kenyataan semuanya dibangun dalam definisi subjektif melalui proses interaksi. Obyektivitas baru bisa terjadi melalui penegasan berulang-ulang yang diberikan oleh orang lain yang memiliki definisi subyektif yang sama. Pendek kata, Berger dan Luckmann mengatakan terjadi dialektika antara individu menciptakan masyarakat dan masyarakat menciptakan individu. Proses dialektika ini terjadi melalui eksternalisasi, objektivasi dan internalisasi.

Berger dan Luckmann untuk memahami konstruksi sosial dimulai dengan mendifinisikan apa yang dimaksud dengan kenyataan dan pengetahuan. Kenyataan sosial dimaknai sebagai sesuatu yang tersirat didalam pergaulan sosial yang diungkapkan secara sosial melalui komunikasi lewat bahasa, bekerjasama melalui bentuk-bentuk organisasi sosial dan sebagainya. Kenyataan sosial ditemukan didalam pengalaman intersubyektif. Sedangkan pengetahuan mengenai kenyataan sosial dimaknai sebagai semua hal yang berkaitan dengan penghayatan kehidupan masyarakat dengan segala aspeknya meliputi kognitif, psikomotoris, emosional dan intuitif. Kemudian dilanjutkan dengan meneliti sesuatu yang dianggap intersubyektif tadi, karena Berger menganggap bahwa terdapat subyektivitas dan objektivitas didalam kehidupan manusia dan masyarakatnya. ${ }^{4}$

Teori konstruksi sosial dalam gagasan Berger mengandaikan bahwa agama sebagai bagian dari kebudayaan, merupakan konstruksi manusia.

${ }^{4}$ Burhan Bungin, Konstruksi Sosial Media Massa: Kekuatan Pengaruh Media Massa, Iklan Televisi dan Keputusan Konsumen serta Kritik Terhadap Peter L. Berger dan Thomas Luckmann, (Jakarta: Kencana, 2008), hlm. 14-15. 
Artinya terdapat proses dialektika ketika melihat hubungan masyarakat dengan agama, bahwa agama merupakan entitas yang objektif karena berada diluar diri manusia. Dengan demikian, agama mengalami proses objektivasi, seperti ketika agama berada didalam teks atau menjadi tata nilai, norma, aturan dan sebagainya. Teks atau norma tersebut kemudian mengalami proses internalisasi kedalam diri individu, sebab agama telah diinterpretasikan oleh masyarakat untuk menjadi pedomannya.

Agama juga mengalami proses eksternalisasi karena ia menjadi acuan norma dan tata nilai yang berfungsi menuntun dan mengontrol tindakan masyarakat. ${ }^{5}$ Proses dialektika ketiga momen tersebut, dalam konteks ini dapat dipahami sebagai berikut:

1. Proses Sosial Momen Eksternalisasi

Eksternalisasi yaitu penyesuaian diri dengan dunia sosio-kultural sebagai produk manusia. "Society is a human product". Dengan kata lain, eksternalisasi terjadi pada tahap yang sangat mendasar, dalam suatu pola perilaku interaksi antara individu dengan produk-produk sosial masyarakatnya. Proses ini dimaksud adalah ketika sebuah produk sosial telah menjadi sebuah bagian penting dalam kehidupan seseorang untuk melihat dunia luar. Dengan demikian, tahap ekternalisasi ini berlangsung ketika produk sosial tercipta di dalam masyarakat, kemudian individu mengeksternalisasikan (penyesuaian diri) ke dalam dunia sosio-kulturalnya sebagai bagian dari produk manusia. Didalam momen ini, realitas sosial berupa proses adaptasi dengan teks-teks suci, kesepakatan ulama, hukum, norma, nilai dan sebagainya yang hal itu berada diluar diri manusia. sehingga dalam proses konstruksi sosial melibatkan momen adaptasi diri atau diadaptasikan antara teks tersebut dengan dunia sosiokultural. Adaptasi tersebut dapat melalui bahasa, tindakan dan pentradisian yang dalam khazanah ilmu sosial disebut interpretasi atas teks atau dogma. Karena adaptasi merupakan proses penyesuaian berdasar atas penafsiran, maka sangat dimungkinkan terjadinya variasivariasi adaptasi dan hasil adaptasi atau tindakan pada masing-masing individu. ${ }^{6}$

\section{Proses Sosial Momen Objektivasi}

Obyektivasi yaitu interaksi sosial dalam dunia intersubjektif yang dilembagakan atau mengalami institusionalisasi. "Society is an objective reality". Dengan demikian, individu melakukan obyektivasi terhadap produk sosial, baik penciptanya maupun individu lain. Kondisi ini

\footnotetext{
${ }^{5}$ Peter L. Berger dan Thomas Lukhmann, Op. Cit. 33-36.

${ }^{6}$ Ibid.
} 
berlangsung tanpa harus mereka saling bertemu. Artinya obyektivitas itu bisa terjadi melalui penyebaran opini sebuah produk sosial yang berkembang melalui diskursus opini masyarakat tentang produk sosial.

Obyektivasi ialah proses mengkristalkan kedalam pikiran tentang suatu obyek, atau segala bentuk eksternalisasi yang telah dilakukan dilihat kembali pada kenyataan di lingkungan secara obyektif. Jadi dalam hal ini bisa terjadi pemaknaan baru ataupun pemaknaan tambahan. Proses objektivasi merupakan momen interaksi antara dua realitas yang terpisahkan satu sama lain, manusia disatu sisi dan realitas sosio-kultural disisi lain. Kedua entitas yang seolah terpisah ini kemudian membentuk jaringan interaksi intersubyektif. Pada momen ini juga ada proses pembedaan antara dua realitas sosial, yaitu realitas diri individu dan realitas sosial lain yang berada diluarnya, sehingga realitas sosial itu menjadi sesuatu yang objektif. Dalam proses konstruksi sosial, proses ini disebut sebagai interaksi sosial melalui pelembagaan dan legitimasi. Dalam pelembagaan dan legitimasi tersebut, agen bertugas menarik dunia subyektifitasnya menjadi dunia obyektif melalui interaksi sosial yang dibangun secara bersama. Pelembagaan akan terjadi manakala terjadi kesepahaman intersubjektif atau hubungan subjek-subjek. ${ }^{7}$

3. Proses Sosial Momen Internalisasi

Internalisasi adalah individu-individu sebagai kenyataan subyektif menafsirkan realitas obyektif. Atau peresapan kembali realitas oleh manusia, dan mentransformasikannya sekali lagi dari struktur-struktur dunia obyektif kedalam struktur-struktur dunia subyektif. Pada momen ini, individu akan menyerap segala hal yang bersifat obyektif dan kemudianakan direalisasikan secara subyektif. Internalisasi ini berlangsung seumur hidup seorang individu dengan melakukan sosialisasi. Pada proses internalisasi, setiap indvidu berbeda-beda dalam dimensi penyerapan. Ada yang lebih menyerap aspek ekstern, ada juga juga yang lebih menyerap bagian intern. Selain itu, selain itu proses internalisasi dapat diperoleh individu melalui proses sosialisasi primer dan sekunder.

Internalisasi yaitu individu mengidentifikasi diri di tengah lembagalembaga sosial atau organisasi sosial di mana individu tersebut menjadi anggotanya. "Man is a social product". Internalisasi dalam pengertian umum merupakan dasar; pertama, bagi pemahaman mengenai 'sesama saya' yaitu pemahaman individu dan orang lain; kedua, pemahaman mengenai dunia sebagai sesuatu yang maknawi dari kenyataan sosial. Oleh karena itu, pandangan konstruksi sosial Peter L. Berger dan Thomas Luckmann diperlukan agar peserta didik tidak saja mampu bertindak atau

\footnotetext{
${ }^{7}$ Nur Syam,Op.Cit. 44.
} 
melakukan kegiatan yang mengandung prinsip-prinsip multikultural, namun lebih dari itu karena mereka benar-benar memahami mengapa melakukannya dan memahami nilai-nilai sosial budaya dan agama yang ada didalamnya. Dalam hal ini pemerintah melalui Undang-Undang Nomor 20 Tahun 2003 Tentang Sistem Pendidikan Nasional pasal 12 ayat 1, terkait hak peserta didik yang salah satunya, mendapatkan pendidikan agama sesuai dengan agama yang dianutnya dan diajarkan oleh pendidik yang seagama, yang berarti melakukan eksternalisasi pendidikan agama.

\section{Nilai Pendidikan Multikultural}

Nilai-nilai pendidikan multikultural dalam konteks pendidikan agama, menurut Zakiyuddin Baidhawy terdapat beberapa karakteristik, yaitu: belajar hidup dalam perbedaan, membangun saling percaya (mutual trust), memelihara saling pengertian (mutual understanding), menjunjung sikap saling menghargai (mutual respect), terbuka dalam berpikir, apresiasi dan interdependensi, resolusi konflik dan rekonsiliasi nirkekerasan. ${ }^{8}$

\section{Belajar Hidup dalam Perbedaan}

Selama ini pendidikan konvensional hanya bersandar pada tiga pilar utama yang menopang proses dan produk pendidikan nasional, yakni how to know, how to do, dan how to be; 1) how to know, menitikberatkan pada proses belajar-mengajar itu sendiri, yakni pendidikan sebagai suatu cara mengajarkan bagaiamana siswa belajar secara benar dan baik guna menambah pengetahuan dan pemahaman menurut ukuran-ukuran tertentu yang disepakati. 2) how to do, berarti sekolah sebagai lembaga pendidikan formal mengajarkan siswa tentang cara melakukan sesuatu, dengan kata lain pembekalan keterampilanketerampilan hidup (life skills) secara lebih luas. 3) how to be, menekankan cara menjadi "orang" sesuai dengan kerangka pikir siswa. Meski pada pilar kedua disampaikan keterampilan hidup, namun lebih berkaitan dengan bekal keahlian masing-masing disiplin yang ditekuni siswa. Pendidikan konvensional belum secara mendasar mengajarkan sekaligus menanamkan "keterampilan hidup bersama" dalam komunitas yang plural secara agama, kultural dan etnik.

Disinilah signifikansi hadirnya pilar keempat untuk melengkapi tiga pilar lainya, yaitu how to live and work together with others. Menurut Zakiyuddin Baidahwy, penanaman pilar keempat sebagai jalinan komplementer terhadap tiga pilar lainya dalam praktek pendidikan meliputi proses, yaitu; a) Pengembangan sikap toleran, empati, dan simpati yang

8 Zakiyuddin Baidhawy, Pendidikan Agama Berwawasan Multikultural (Jakarta: Erlangga, 2005), 78-84. 
merupakan prasyarat esensial bagi keberhasilan koeksistensi dan proeksistensi dalam keragaman agama; b) Klarifikasi nilai-nilai kehidupan bersama menurut perspektif agama-agama; c) Pendewasaan emosional; dan d) Kesetaraan dalam partisipasi. ${ }^{913}$

2. Membangun saling percaya (mutual trust)

Rasa saling percaya adalah salah satu modal sosial (social capital) terpenting dalam penguatan kultural masyarakat madani. Modal sosial, yang sesuai dengan modal ekonomi dan modal simbolik, secara sederhana dapat didefenisikan sebagai seperangkat nilai -nilai atau norma-norma informal yang dimiliki bersama para anggota suatu kelompok masyarakat yang mendorong terjadinya kerjasama satu dengan yang lain. Saling percaya satu sama lain merupakan jalan keluar untuk mendamaikan semua keadaan. Sebaiknya kita tidak boleh saling membangun opini untuk membenarnya sikap kita sendiri. Justru yang harus kita lakukan ialah membangun kepercayaan itu perlu perjuangan, keterbukaan, kejujuran, mengejar kualitas, kebenaran dan kebaikan bersama.

\section{Memelihara saling pengertian (mutual understanding)}

Saling memahami adalah kesadaran bahwa nilai-nilai mereka dan kita dapat berbeda dan mungkin saling melengkapi serta memberi kontribusi terhadap relasi yang dinamis dan hidup, sehingga oposan merupakan mitra yang saling melengkapi dan kemitraan menyatukan kebenarankebenaran parsial dalam suatu relasi.

Kawan sejati adalah lawan dialog yang senantiasa setia untuk menerima perbedaan dan siap pada segala kemungkinan untuk menjumpai titik temu di dalamnya, serta memahami bahwa dalam perbedaan dan persamaan, ada keunikan -keunikan yang tidak dapat secara bersama-sama oleh partisipan dalam kemitraan. Untuk itu, Pendidikan Agama mempunyai tanggung jawab membangun landasan etis kesaling sepahaman antara entitas-entitas agama dan budaya yang plural, sebagai sikap dan kepedulian bersama.

4. Menjunjung sikap saling menghargai (mutual respect)

Sikap ini mendudukan semua manusia dalam relasi kesetaraan, tidak ada superioritas maupun inferioritas. Menghormati dan menghargai sesama manusia adalah nilai universal yang dikandung semua agama di dunia. Pendidikan agama berwawasan multikultural menumbuh kembangkan kesadaran bahwa kedamaian mengandaikan saling menghargai antar penganut agama-agama, yang denganya kita dapat dan

${ }^{9}$ Ibid, $79-80$. 
siap untuk mendengarkan suara dan perspektif agama lain yang berbeda; menghargai signifikansi dan martabat semua individu dan kelompok keagamaan yang beragam. Untuk menjaga kehormatan dan harga diri tidak harus diperoleh dengan mengorbankan kehormatan dan harga diri orang lain apalagi dengan menggunakan sarana dan tindak kekerasan. Saling menghargai membawa pada sikap saling berbagi di antara semua individu dan kelompok.

\section{Terbuka dalam Berpikir}

Kematangan berpikir merupakan salah satu tujuan penting pendidikan. Pendidikan seyogyanya memberi pengetahuan baru tentang bagaimana berpikir dan bertindak bahkan mengadopsi dan mengadaptasi sebagian pengetahuan baru itu pada diri siswa. Sebagai akibat dari perjumpaan dengan dunia lain, agama -agama dan kebudayan-kebudayaan yang beragam, siswa mengarah pada proses pendewasaan dan memiliki sudut pandang dan banyak cara untuk memahami realitas.

\section{Apresiasi dan Interdependensi}

Kehidupan yang layak dan manusiawi hanya mungkin tercipta dalam sebuah tatanan sosial yang care, dimana semua anggota masyarakatnya dapat saling menunjukkan saling apresiasi dan memelihara relasi, keterikatan, kohesi dan kesalingkaitan sosial yang rekat.

Banyak sisi kehidupan manusia yang tidak dapat diatasi secara material oleh limpahan harta, uang, tahta, dan kekayaan. Ada kebutuhan untuk saling menolong atas dasar kecintaan dan ketulusan terhadap sesama manusia, untuk mengatasi ketidakberdayaan (powerlessness), ketidakpastian (contingency), dan kelangkaan (scarcity). Perlu tanggung jawab untuk menciptakan bersama sebuah masyarakat yang membantu semuanya. ${ }^{10}$ Tatanan sosial yang harmoni dan dinamis yang saling terkait mendukung individu -individu dan bukan memecah belah mereka.

7. Resolusi Konflik dan Kesadaran Multikultural

Konflik antar agama adalah kenyataan yang tak terbantahkan dari masa lalu dan masa kini kita. Namun konflik ini harus dikurangi sedemikian rupa karena dengan satu atau lain alasan, konflik berarti mengangkangi nilai-nilai agama tentang persaudaraan (ukhuwahalbasyariyah) dan persatuan umat manusia (unity of humankind). ${ }^{11}$ Dalam situasi konflik, Pendidikan Agama harus hadir untuk menyuntikkan spirit dan kekuatan spiritual sebagai sarana integrasi dan kohesi sosial, ia juga menawarkan angim segar bagi kedamaian dan perdamaian.

${ }^{10} \mathrm{Ibid}, 84$.
${ }^{11} \mathrm{Ibid}, 84$. 
Dengan kata lain, Pendidikan Agama perlu memfungsikan agama sebagai suatu cara dalam sosial multikultural.

Resolusi konflik belum cukup tanpa rekonsiliasi, yakni upaya perdamaian melalui sarana pengampunan atau memaafkan (forgiveness). Pemberian ampun atau maaf dalam rekonsiliasi adalahtindakan tepat dan terpuji dalam situasi konflik. Pendidikan Agama perlu meyakinkan bahwa agama-agama sesungguhnya mengajarkan bahwa "balasan untuk suatu kejahatan adalah kejahatan yang serupa denganya. Tetapi jika seseorang memberi maaf dan rekonsiliasi, balasanya adalah dari Tuhan".

\section{Eksternalisasi Nilai Pendidikan Multikultural Dalam Pembelajaran Pendidikan Agama Islam Berbasis Multiagama}

Agama adalah sumber nilai dan norma bagi manusia dalam membentuk tatanan kehidupan sosial yang dinamis demi kebahagiaan manusia itu sendiri, baik kebahagiaan individual maupun sosial. Nilai-nilai dan norma-norma dari semua ajaran agama, pada hakikatnya adalah sama, yaitu ajaran pada keselamatan dan kebahagiaan di dunia dan akhirat.

Jika dispesifikkan lagi maka dapat dikatakan bahwa semua ajaran agama mengandung nilai-nilai multikultural yang dicita-citakan dapat termanisfestasi dalam kehidupan beragama. Multikultural agama tidak semata menunjuk pada kenyataan tentang adanya kemajemukan agama. Namun yang dimaksud adalah keterlibatan aktif terhadap kenyataan kemajemukan tersebut. Multikultural agama dan budaya dapat dijumpai dimana-mana. Di dalam masyarakat tertentu, di kantor tempat bekerja, di sekolah tempat belajar, bahkan di pasar tempat berbelanja. Dengan kata lain, pengertian multikultural agama adalah bahwa setiap pemeluk agama dituntut bukan saja mengakui keberadaan dan hak agama lain, tapi terlibat dalam usaha memahami perbedaan dan persamaan guna tercapainya kerukunan, kedamaian dan keharmonisan mansuia dalam kemajemukan agama. Multikultural agama adalah sebuah kenyataan perbedaan agama yang mengandaikan terjadinya transformasi nilai-nilai yang terkandung di baliknya. Karena, sebagaimana yang diutarakan oleh Pierre Gauthy, bahwa perbedaan yang terdapat pada masing-masing orang mempunyai nilai dan merupakan sumber untuk saling memperkaya diri. Kebhinekaan dalam masyarakat dapat merupakan sumber kemajuan. ${ }^{12}$

Suatu nilai itu pada hakikatnya tersembunyi di balik tindakan dan sikap individu atau masyarakat. Nilai itu tidak dapat ditemukan dalam bentuknya sendiri, melainkan sesuatu yang ada di balik tindakan-tindakan

12 Pierre Gauthy dkk., Pendidikan Nilai Memasuki Tahun 2000, (Jakarta: PT Grasindo, 1993), 117. 
masyarakat sekolah, terutama peserta didik, sejauh mereka bertindak secara manusiawi. Nilai-nilai kemanusiaan dan nilai-nilai multikultural agama hanya akan terlihat jika peserta didik saling menhormati, saling menghargai, berlaku adil, tidak berbuat kekerasan, tidak membeda-bedakan teman dengan melihat latar belakang agama, bekerja sama, dan beradab terhadap sesama, baik terhadap sesama penganut agamanya maupun terhadap penganut agama lain, dan juga terhadap semua masyarakat sekolahnya. Nilai-nilai multikultural tersebut, tidak disadari oleh peserta didik tanpa pengarahan dan bimbingan dari seorang guru di sekolah, lebih-lebih guru pendidikan agama Islam (PAI), baik melalui lembaga pendidikan umum maupun lembaga pendidikan agama secara khusus, baik melalui proses pengajaran secara formal maupun melalui kegiatan-kegiatan keagamaan dan ekstrakurikuler.

Implementasi tersebut selain memberikan tugas-tugas kemanusiaan seperti gotong royong kebersihan dilingkungan sekolah dan sekitarnya, kerjasama dalam setiap tugas kelompok, para pendidik khususnya pendidik SMKN 3 Pamekasan juga memberikan keteladanan dengan memberikan contoh ikut terlibat langsung dalam setiap kegiatan. Proses implementasi yang dilaksanakan pendidik SMKN 3 Pamekasan sebagaimana telah dikemukakan tersebut dapat dikatakan baik. Memberikan keteladanan yang baik dan menanamkan sikap kemanusian berupa kepedulian terhadap lingkungan kelas dan sekitarnya melalui gotong royong akan menumbuhkan semangat kebersamaan yang melahirkan kepekaan sosial dalam diri setiap peserta didik.

Penerapan pembagian tugas kelompok yang dikerjakan secara bersama-sama tentu dapat memupuk sikap kerjasama diantara peserta didik. Dengan dilakukan secara berkesinambungan diharapkan proses konstruksi nilai-nilai pendidikan multikultural yang dilakukan oleh pendidik dapat pula memupuk sikap toleransi yang tinggi di antara peserta didik sehingga dapat menumbuhkan perdamaian dan kedamaian dalam lingkungan kelas. Prinsipprinsip dari behaviorisme memberikan strategi-strategi membantu peserta didik mengembangkan dan mempertahankan prilaku yang lebih produktif di kelas.

Prinsip-prinsip teori kognitif sosial menunjukkan kepada kita bagaimana kita dapat mencontohkan (memodelkan) secara efektif model keterampilan -keterampilan yang kita inginkan untuk dikuasai peserta didik dan bagaimana kita dapat mendorong pengaturan diri yang lebih besar. ${ }^{13}$ Sesuai dengan hal tersebut di atas sebagaimana dijelaskan

13 Jeanne Ellis Ormrod, Psikologi Pendidikan: Membantu Siswa Tumbuh dan Berkembang, Jilid 2, edisi ke 6, dalam judul Asli Educational Psycology Developing Learners, Alih Bahasa Amitya Kumara, (Jakarta: Erlangga, 2008), 52. 
dalam Imron Mashadi mengutip beberapa pendapat tentang pendidikan mulikultural sebagaimana disebutkannya, menurut Rosyada ${ }^{14}$ pendidikan multikultural sebagai pendidikan keragaman budaya dalam masyarakat, dan terkadang jugadiartikan sebagai pendidikan untuk membina sikap peserta didik agar menghargai keragaman budaya masyarakat.

Masih dalam Mashadi, Crendall bersama Banks dan Banks melihat dan mendefinisikan pendidikan multikultural sebagai bidang kajian dan disiplin yang muncul dengan tujuan utamanya meciptakan kesempatan pendidikan yang setara bagi peserta didik tentang ras, etnik, kelas sosial dan kelompok budaya yang berbeda. Ainul Yaqin ${ }^{15}$ menyimpulkan bahwa makna pendidikan multikultural bertujuan melatih dan membangun karakter peserta didik agar mampu bersikap demokratis, humanis, dan pluralis dalam lingkungan mereka.

Beberapa pendapat para ahli tersebut telah menunjukkan bahwa implementasi pendidikan multikultural yang telah dilaksanakan di SMKN 3 Pamekasan pada mata pelajaran Pendidikan Agama Islam dan Budi Pekerti telah sesuai dengan teori yang telah ada. Pendidikan multikultural merupakan proses pendidikan yang komprehensif dan mendasar bagi semua peserta didik. Jenis pendidikan ini menentang segala bentuk rasisme dan segala bentuk diskriminasi di sekolah dan masyarakat dengan menerima dan mengafirmasi pluralitas yang tereflekasikan di antara peserta didik, komunitas mereka dan guru-guru. Pendidikan multikultur harus melekat dalam kurikulum dan strategi pengajaran, termasuk dalam setiap interaksi yang dilakukan di antara para guru, murid dan keluarga serta keseluruhan suasana belajar mengajar. Jenis pendidikan ini merupakan paedagogi kritis, reflektif dan menjadi basis aksi perubahan dalam masyarakat, maka pendidikan multikultural mengembangkan prinsip-prinsip demokrasi dalam berkeadilan sosial.

Begitu pula halnya SMKN 3 Pamekasan, yang merupakan lembaga pendidikan yang menampung berbagai macam peserta didik yang terdiri dari beragam agama seperti agama Islam yang merupakan mayoritas, agama Kristen Katolik, dan Budha, tentunya harus berusaha untuk menemukan nilai-nilai di balik multikultural masyarakat sekolahnya dan kemudian menanamkannya kepada diri setiap peserta didik. Oleh karena itu, peneliti berusaha untuk menemukan nilai-nilai pendidikan multikultural dalam pembelajaran pendidikan agama Islam berbasis multiagama di SMKN 3 pamekasan yang kemudian pada akhirnya dapat peneliti tegaskan bahwa di

${ }^{14}$ Imron Mashadi, Reformasi Pendidikan Agama Islam(PAI) di Era Multikultural dalam Zainal Abidin, EP, Pendidikan Agama Islam dalam Perspektif Multikulturalisme, (Jakarta: Saadah Cipta Mandiri, 2009), 47-48.

15 Ainul Yaqin, Pendidikan Multikultural, (Yogyakarta: Pilar Media. 2005), 26. 
SMKN 3 pamekasan, sesungguhnya nilai-nilai tersebut telah diaktualisasikan dalam kehidupan sosial beragama di sekolah, walaupun keberadaan nilai-nilai tersebut tidak disadari secara mendalam. Lebih jauh, sekiranya para pelaku pendidikan mau menyadari, tentunya dapat diketahui bahwa sekolah merupakan sebuah bentuk masyarakat kecil yang terdiri dari guru, siswa, karyawan dan staf-staf yang terdiri dari beragam latar belakang agama, kelas sosial, suku, dan budaya.

Adapun nilai-nilai agama islam yang dikembangkan di SMKN 3 Pamekasan atara lain ialah; Pertama, Nilai kesamaan, nilai kesamaan ini tercermin dari kebijakan sekolah yang memandang secara umum tanpa membeda-bedakan suku, bahasa, agama dan kondisi ekonomi sosialnya dan kegiatan pembelajaran serta kondisi lingkungan di SMKN 3 Pamekasan. Berdasarkan hasil penelitian yang telah dipaparkan pada bab sebelumnya, di SMKN 3 Pamekasan menjunjung tinggi nilai kesamaan sebagai bagian dari upaya membangun toleransi di sekolah;

Kedua, Nilai kebebasan, berdasarkan hasil observasi, wawancara, dan dokumentasi oleh peneliti di SMKN 3 Pamekasan mengenai nilai kebebasan. Analisis pertama, berdasarkan fakta dilapangan bahwa ketika dihadapkan dengan siswa yang berbeda agama, maka guru PAI memberikan kebebasan sepenuhnya kepada siswa yang berbeda agama. Guru PAI tidak pernah memaksankan kehendak apapun terkait dengan kegiatan pembelajaran agama di kelas, guru memberikan kesempatan kepada siswa khususnya siswa non muslim untuk tidak mengikuti atau mengikuti kegiatan pembelajaran Agama Islam di kelas; dan

Ketiga, Nilai Keadilan, adil bukan berarti sama, adil berarti semua pihak mendapatkan hak dan kewajibannya. Dari hasil penelitian melalui observasi, wawancara, dan dokumentasi, penerapan nilai keadilan di SMKN 3 Pamekasan terwujud dari upaya guru PAI dalam memberikan keadilan didalam kelas maupun kebijakan sekolah dalam memenuhi hak dan kewajiban seluruh warga sekolah. Kebutuhan spiritual sudah dirasakan oleh seluruh siswa meskipun ada beberapa siswa yang masih membutuhkan perlakuan khusus terkait dengan pemenuhan hak dan kewajibannya dalam mendapatkan pengetahuan agama.

\section{Objektivasi Nilai Pendidikan Multikultural Dalam Pembelajaran Pendidikan Agama Islam Berbasis Multiagama}

Keberhasilan Pendidikan multikultural dengan keluaran menghasilkan peserta didik yang memiliki kompetensi personal dan kompetensi sosial yang pluralis dan dinamis sehingga menghasilkan warga Negara yang baik (good citizen). Kesuksesan pendidikan multikultural tidak diukur dengan penguasaan nilai-nilai diskriminasi dan 
inklusifisme serta soft skills yaitu kemampuan bekerja kelompok secara inklusif (mudah menerima masukan) anti diskriminasi, egalitarian, memimpin secara demokratis, adil terhadap sesama, kemapuan berkordinasi, humanis kemampuan berkomunikasi, berempati kepada orang lain yang menekankan kebersamaan dan keteladanan pemimpin dalam kehidupan multikultural. Berdasarkan Peraturan Menteri Pendidikan Nasional Nomor 23 Tahun 2006 Tanggal 23 Mei 2006 tentang Standar Kompetensi Lulusan, didalamnya menyebutkan bahwa standar kompetensi lulusan satuan pendidikan pada semua jenjang pendidikan peserta didik mampu menghargai keberagaman agama, budaya, suku, ras, dan golongan social ekonomi di lingkungan sekitarnya. ${ }^{16}$ Selanjutnya Muhaimin menjelaskan bahwa strategi untuk membudayakan nilai-nilai agama di sekolah dapat dilakukan melalui: (1) Power strategi, yakni strategi pembudayaan agama di sekolah dengan cara menggunakan kekuasaan atau melalui people's power, dalam hal ini peran kepala sekolah dengan segala kekuasaannya sangat dominan dalam melakukan perubahan; (2) persuasive strategy, yang dijalankan lewat pembentukan opini dan pandangan masyarakat warga sekolah/madrasah; dan (3) normative re-educative, artinya norma yang berlaku di masyarakat termasyarakatkan lewat education, dan mengganti paradigma berpikir masyarakat sekolah/madrasah yang lama dengan yang baru. Pada strategi pertama tersebut dikembangkan melalui pendekatan perintah dan larangan atau reward dan punishment, sedangkan strategi kedua dan ketiga tersebut dikembangkan melalui pembiasaan, keteladanan, dan pendekatan persuasif atau mengajak pada warganya dengan cara yang halus, dengan memberikan alasan dan prospek baik yang bisa menyakinkan mereka. ${ }^{17}$

Konsep nilai-nilai pendidikan multikultural yang dikembangkan sekolah telah diterapkan kepada peserta didik melalui kegiatan keagamaan, sosial dan kegiatan ekstrakurikuler. Kesadaran masyarakat akan pentingnya pendidikan bagi peserta didik (anak) perlu ditingkatkan, mengingat pendidikan merupakan salah satu unsur yang melekat pada diri manusia sebagai hak yang harus diterimanya. Serta pendidikan akan membawa masyarakat itu sendiri menuju kepada kemajuan, baik kemajuan dalam politik, ekonomi, sosial, dan budaya. Kemajuan yang diharapkan oleh masyarakat yaitu ketenteraman, kerukunan, serta terhindar dari berbagai macam bentuk konflik. Karena pada dasarnya masyarakat multikultural tidak hanya ciri khas masyarakat Indonesia.Dalam pengalaman paling dini

\footnotetext{
${ }^{16}$ Peraturan Menteri Pendidikan Nasional Nomor 23 Tahun 2006 Tanggal 23 Mei 2006

17 Muhaimin, Nuansa Baru Pendidikan Islam; Mengurai Benang Kusut Dunia Pendidikan, Jakarta: Raja Grafindo Persada, 2006), 136. 
historisitas keberagamaan Islam era kenabian Muhammad SAW, masyarakat yang pluralistik secara religius telah terbentuk bahkan telah menjadi kesadaran umum pada saat itu.

Konsep Pendidikan multikultural didukung dalam materi pembelajaran pendidikan agama Islam dan kegiatan keagamaan yang ada disekolah. Kompetensi, materi, dan pembelajaran Pendidikan Agama Islam dan Budi Pekerti dikembangkan melalui pertimbangan kepentingan hidup bersama secara damai dan harmonis (to live together in peace and harmony). Pembelajaran dilaksanakan berbasis aktivitas pada kegiatan intrakurikuler, kokurikuler, dan/atau ekstrakurikuler.

Penumbuhan dan pengembangan sikap dilakukan sepanjang proses pembelajaran, pembiasaan, keteladanan, dan pembudayaan untuk mengembangkan karakter peserta didik lebih lanjut. Sekolah sebagai taman yang menyenangkan untuk tumbuh berkembangnya sikap, pengetahuan, dan keterampilan peserta didik yang menempatkan pengetahuan sebagai perilaku (behavior), tidak hanya berupa hafalan atau verbal. Bukti empiris sejarah peradaban Islam di masa lalu, menunjukkan Islam tampil secara inklusif dan sangat menghargai non-muslim. Sikap inklusif ini ada karena al-Qur'an mengajarkan paham religius plurality. Bagi orang Islam, dianut suatu keyakinan bahwa sampai hari ini pun di dunia ini akan terdapat keragaman agama. Nilai-nilai karakter yang ditanamkan peserta didik di SMKN 3 Pamekasan tidak lepas dari adanya kuriulum tertulis sekolah ini seperti pembelajaran di kelas maupun di luar kelas lalu juga adanya kurikulum tersembunyi mulai dari adanya rumusan tata tertib, kegiatan ekstrakurikuler, acara-acara sosial-keagamaan dalam momen tertentu untuk melatih peserta didik agar bisa bersikap peduli kepada sesama manusia atau lingkungan sekitar, bersedia untu selalu berbuat kebaikan, peduli, empatik, tanggung jawab, tolong-menolong, jujur, tidak mengambil hak orang lain, dan sebagainya. Beberapa nilai yang dikembangkan di SMKN 3 Pamekasan, seperti mengedepankan nilai toleransi antara siswa dan guru misalnya tidak membedakan siswa yang pintar atau yang kurang pintar, kaya atau miskin. Nilai Kekeluargaan misalnya Guru melayani siswa dan bersedia menjadi pengganti orang tua. Nilai Ramah Lingkungan Menciptakan suasana KBM yang kondusif dari nilai tersebut agar bisa Memberikan kesadaran pada siswa tentang kesadaran menjunjung tinggi nilai-nilai perdamaian, pentingnya untuk saling menghargai diantara sesama teman/ masyarakat. 


\section{Internalisasi Nilai-nilai Pendidikan Multikultural Dalam Pembelajaran Pendidikan Agama Islam Berbasis Multiagama}

Menurut Peter L. Berger proses internalisasi adalah proses yang berlangsung sepanjang hidup individu, yaitu mulai saat ia dilahirkan sampai akhir hayat. Sepanjang hayatnya seorang individu terus belajar untuk mengelola segala perasaan, hasrat nafsu dan emosi yang mmbentuk kepribadiannya. Tetapi wujud dan pengaktifannya sangat dipengaruhi oleh berbagai macam situasi yang berada dalam alam sekitar, lingkungan sosial maupun budayanya. ${ }^{18}$ Pendidikan Agama Islam adalah upaya sadar dan terencana dalam menyiapkan peserta didik untuk mengenal, memahami, menghayati, agar beriman, bertakwa dan berakhlak mulia dalam mengamalkan ajaran agamanya.

Kegiatan pendidikan agama Islam dilakukan melalui bimbingan, pengajaran, latihan, serta pengunaan pengalaman dan pembiasaan dalam kehidupan sehari-hari. Dalam upaya menginternalisasikan nilai-nilai Pendidikan Agama Islam (PAI) pada siswa agar tercermin pada perilaku mereka khususnya terhadap perilaku saling menghargai (toleransi) antar agama, maka diperlukan suatu penciptaan budaya religius sekolah. Oleh karena guru PAI mempunyai posisi penting dalam pendidikan karena dia merupakan satu target dari strategi pendidikan ini. Apabila seorang guru memiliki kemampuan untuk mengenalkan dan menanamkan nilai-nilai pendidikan agama Islam, maka dia juga akan mampu menumbuhkan kesadaran pada siswa dalam rangka mewujudkan pribadi muslim seutuhnya.

Internalisasi nilai-nilai pendidikan multikultural sudah mulai tertanamkan kepada Bapak dan Ibu guru PAI bahwa mendidik peserta didik tidak harus dengan menggunakan kekerasan, tetapi lebih menggunakan pendekatan personal. Mengatasi permasalahan peserta didik, guru tidak perlu melakukan kekerasan dengan cara dan dalam bentuk apa pun. Dalam kondisi terpaksa guru boleh memberikan hukuman sepanjang dalam batas-batas yang di perbolehkan dan dilakukan dalam rangka mendidik peserta didik. Kenakalan dan kekerasan peserta didik menunjukkan adanya permasalahan pada dirinya, dimana mereka memandang perbedaan dan keberagaman tersebut hanya secara dangkal.

Nilai-nilai dari pendidikan multikultural melalui Pendidikan Agama Islam bahwasannya dampaknya besar bagi peserta didik dalam kehidupan sehari-hari yaitu peduli dengan lingkungan, berakhlak mulia, sopan dan santun, saling toleran, saling menghargai dan menghormati, belajar demokrasi dalam pengambilan keputusan dan diskusi. Semua kegiatan

${ }^{18}$ Geger Riyanto dan Peter L Berger, Perspektif Metateori Pemikiran, (Jakarta: LP3ES Indonesia. 2009). 112. 
melalui keagamaan berimplikasi besar dalam kehidupan sehari hari dan berpengaruh nantinya setelah mereka lulus serta mengaplikasikannya dalam masyarakat.

Internalisasi nilai-nilai pendidikan berbasis multiagama di SMKN 3 Pamekasan sudah banyak dilakukan seperti halnya dalam kegiatan ibadah yang dilaksanakan dalam kehidupan sehari-hari seperti peduli pada teman dan masyarakat, punya tanggung jawab dan toleran ketika berorganisasi atau kelompok. Toleransi sebagai makhluk sosial manusia tentunya harus hidup sebuah masyarakat yang kompleks akan nilai karena terdiri dari berbagai macam suku dan agama. Toleransi dikenal secara luas sebagai suatu sikap atau perilaku manusia yang tidak menyimpang dari aturan, dimana seseorang menghargai atau menghormati setiap tindakan yang orang lain lakukan. Dalam pengamatan peneliti bahwa memang benar anak-anak melakukan semua program kegiatan yang di jadwalkan oleh sekolah dengan penuh kesadaran diri dan tanggung jawab untuk melaksanakannya. Terlihat ketika mereka melakukan aktivitas jum'at bersih di sekolah, meskipun guru tidak selalu mendampingi langsung selama kegiatan tersebut, peserta didik sendiri dengan teman-teman sekelompoknya yang begitu antusias melakukan aktivitas tersebut. Sopan dan santun serta saling menghormati kepada warga sekolah tanpa perintah maupun ajakan dari guru mereka melakukannya sendiri.

Pendidikan adalah suatu usaha sadar yang dilakukan oleh pendidik melalui bimbingan atau pengajaran dan latihan untuk membantu peserta didik mengalami proses pemanusiaan diri ke arah tercapainya pribadi dewasa, susila dan dinamis. Pendidikan multikultural mensosialisasikan nilai-nilai, norma-norma tingkah laku manusia yang harus dan wajib dilakukan dalam kehidupan masyarakat yang mengedepankan nilai-nilai musyawarah dalam demokrasi dan perdamaian dengan selalu menjunjung sikap saling menghormati dengan sesama bahkan dengan antar umat beragama.

Keberhasilan dari konsep dan proses internalisasi nilai-nilai pendidikan multikultural melalui pendidikan agama Islam tidak hanya diukur sepenuhnya, namun disesuaikan dengan kebutuhan dan menyesuaikan dengan tuntutan zaman yang terus maju. Dan pasti tiap sekolah menginginkan yang terbaik untuk peserta didiknya sehingga sekolah berusaha memenuhi segala tuntutan kebutuhan-kebutuhan yang ada. Implikasi besar bagi anak-anak dari internalisasi nilai-nilai pendidikan multikultural melalui kegiatan keagamaan yaitu anak-anak taat dan rajin melaksanakan sholat, akhlak dan etika yang semakin baik seperti halnya dalam halnya ketika ketemu guru menyapa dan bersalaman, sebagai wujud nilai kebudayaan keagamaan. Sementara ini hasil yang telah dicapai cukup 
memuaskan peserta didik semakin disiplin, selalu senyum, salim dan sapa kepada bapak ibu guru, melakukan kegiatan dengan penuh kesadaran, tidak adanya tawuran antar pelajar di lingkungan sekolah, guru dan peserta didik saling menghargai perbedaan masing-masing, guru tidak lagi diskriminatif dalam mendidik tapi lebih kepada saling menghargai dan menghormati serta toleran kepada mereka yang memiliki keyakinan agama yang berbeda.

Pendidikan multikultural dapat terinternalisasi dengan baik dengan adanya kerjasama antara sekolah, guru, orang tua, masyarakat dan lingkungan sekitar. Hal ini dapat peneliti simpulkan berkurangnya tindakan diskriminatif di SMKN 3 Pamekasan seperti : ujaran kebencian (hate speech) terhadap peserta didik yang berbeda keyakinan, kenakalankenakalan remaja yang didasari oleh kebencian terhadap perbedaan suku atau etnis dan lain-lain. Terbiasa berperilaku sopan dan santun kepada bapak ibu guru, hormat kepada yang lebih tua dan mengasihi yang lebih muda, gemar beribadah. Merupakan bukti keberhasilan SMKN 3 Pamekasan menginternalisasikan nilai pendidikan multikultural dalam pembelajaran pendidikan agama islam berbasis multiagama.

\section{KESIMPULAN}

Konstruksi nilai-nilai pendidikan multikultural dalam pembelajaran pendidikan agama Islam berbasis multiagama di SMKN 3 Pamekasan terimplementasi melalui; Pertama, Eksternalisasi melalui upaya menanamkan dan menumbuhkembangkan perasaan cinta kasih dan saling menghormati diantara manusia yang pada dasarnya memiliki perbedaanperbedaan agama, etnis, suku, dan ras. Sehingga dalam penyampaian materi tidak boleh memihak satu paham tertentu. Proses ini memberikan pemahaman dengan menguatkan pada setiap peserta didik melalui budaya keagamaan, mata pelajaran pendidikan Agama Islam, kegiatan ekstrakurikuler dan intrakurikuler. Nilai-nilai pendidikan multikultural dapat diimplementasikan dengan memberikan keteladanan dari seorang guru, menciptakan komunitas yang bermoral dikelas seperti toleransi, kesamaan, kesopanan, keadilan;

Kedua, Objektivasi melalui interaksi antara guru dan peserta didik saat menjalankan proses pendidikan maupun pembelajaran, dan guru memberikan contoh hal yang baik kepada peserta didik dengan berperilaku toleransi, demokratis, adil tanpa pandang bulu, sopansantun serta saling menghormati. Usaha sungguh-sungguh yang melibatkan tiga aspek dalam peserta didikmeliputi kognitif, afektif dan psikomotorik peserta didik akan bisa merasakan, dan selanjutnya akantimbul kemauan untuk benar-benar melakukan perbuatan yangmencerminkankarakter mulia (good character). 
Ketiga, Proses internalisasiyang dimulai darisosialisasi bapak dan ibu guru ataupun karyawan sekolah.

Internalisasi dengan memasukkan nilai agama secara penuh ke dalam hati peserta didik, sehingga mereka bersikap dan berperilaku berdasarkan ajaran agama Islam, selanjutnya dapat direalisasikan dalam kehidupan sehari-hari. Sehingga dengan penanaman nilai-nilai pendidikan Agama Islam dapat memberikan bekal kepada peserta didik untuk menumbuhkan kesadaran dan mengembangkan segi-segi kehidupan spiritual yang baik dan benar dalam rangka mewujudkan pribadi muslim seutuhnya.

\section{DAFTAR PUSTAKA}

Ainul Yaqin, 2005, Pendidikan Multikultural, Yogyakarta: Pilar Media.

Burhan Bungin, 2008, Konstruksi Sosial Media Massa: Kekuatan Pengaruh Media Massa, Iklan Televisi dan Keputusan Konsumen serta Kritik Terhadap Peter L. Berger dan Thomas Luckmann, Jakarta: Kencana.

Geger Riyanto dan Peter L Berger, 2009, Perspektif Metateori Pemikiran, Jakarta: LP3ES Indonesia.

Imron Mashadi, 2009, Reformasi Pendidikan Agama Islam(PAI) di Era Multikultural dalam Zainal Abidin, EP, Pendidikan Agama Islam dalam Perspektif Multikulturalisme, Jakarta: Saadah Cipta Mandiri.

Jeanne Ellis Ormrod, 2008, Psikologi Pendidikan: Membantu Siswa Tumbuh dan Berkembang, Jilid 2, edisi ke 6, dalam judul Asli Educational Psycology Developing Learners, Alih Bahasa Amitya Kumara, Jakarta: Erlangga.

Lexy J. Moleong, 2008. Penelitian kualitatif. Bandung : PT Remaja Rosdakarya.

Muhaimin, 2006, Nuansa Baru Pendidikan Islam; Mengurai Benang Kusut Dunia Pendidikan, Jakarta: Raja Grafindo Persada.

Nur Syam, 2005, Islam Pesisir, Yogyakarta: LKis Pelangi Aksara.

Peraturan Menteri Pendidikan Nasional Nomor 23 Tahun 2006 Tanggal 23 Mei 2006.

Peter Berger, L dan Thomas Luckmann, 1991. Tafsir Sosial atas Kenyataan: Risalah tentang Sosiologi Pengetahuan, Jakarta: LP3ES. , Langit Suci: Agama sebagai Realitas Sosial Jakarta: LP3ES.

Pierre Gauthy dkk., 1993, Pendidikan Nilai Memasuki Tahun 2000, Jakarta: PT Grasindo.

Zakiyuddin Baidhawy, 2005, Pendidikan Agama Berwawasan Multikultural, Jakarta: Erlangga. 